\title{
Correction to: Exposure to catastrophe risk and use of reinsurance: an empirical evaluation for the U.S.
}

\author{
Alejandro Drexler ${ }^{1} \cdot$ Richard Rosen $^{1}$
}

Published online: 23 September 2020

(c) The Author(s) 2020

\section{Correction to: The Geneva Papers on Risk and Insurance - Issues and Practice https://doi.org/10.1057/s41288-020-00186-3}

The authors would like to add the following Federal Reserve Bank disclosure and acknowledgement to their article: The opinions expressed here do not represent official positions of the Federal Reserve Bank of Chicago or the Federal Reserve System. We would like to thank Daniel Bauer, Daniel Hartley, Thomas King, Tyler Leverty, Andy Polacek and the participants in the Western Economic Association International 2016 annual conference for their comments.

Publisher's Note Springer Nature remains neutral with regard to jurisdictional claims in published maps and institutional affiliations.

The original article can be found online at https://doi.org/10.1057/s41288-020-00186-3.

Alejandro Drexler

alejandro.h.drexler@chi.frb.org

Richard Rosen

Richard.rosen@chi.frb.org

1 Federal Reserve Bank of Chicago, 230 S LaSalle, Chicago, IL 60604, USA 